\title{
Taxonomic status of Dimeria veldkampii (Andropogoneae: Poaceae)
}

\author{
Kolte R.R. ${ }^{{ }^{*}}$, Gosavi K.V.C. ${ }^{2}$ \& M.K. Janarthanam ${ }^{1}$ \\ ${ }^{1}$ Department of Botany, Goa University, Goa - 403 206, India. \\ 2Department of Botany, HPT Arts \& RYK Science College, Nashik, Maharashtra - 422 005, India. \\ "E-mail: rutuja24kolte@gmail.com
}

\begin{abstract}
Dimeria veldkampii Kiran Raj \& Sivad. is shown to be conspecific with D. woodrowii Stapf as the range of morphological variations are continuous. Hence, it is subsumed under D. woodrowii.
\end{abstract}

Keywords: Conspecific, Dimeria woodrowii, Lateritic plateau, Range of variation.

\section{Introduction}

Dimeria R.Br., one of the dominant genera of the family Poaceae on lateritic plateaus, comprises of $c$. 64 species in the world mostly distributed in tropical regions of Asia (Clayton et al., 2006; Mabberley, 2017). More than 50\% taxa (37 species) of this genus are reported from Peninsular India (Ravi et al., 2001; Kiran Raj, 2008; Gosavi et al., 2016) of which Dimeria woodrowii Stapf is endemic to northern parts of Western Ghats (Nayar et al., 2014; Singh et al., 2015) especially along the low elevation lateritic plateaus. It is considered to be a highly evolved species and hence has been kept in a separate section, viz. sect. Annulares (Bor, 1952). The coiling of racemes to form circinate hoop is a unique character in tribe Andropogoneae. Subsequently, Kiran Raj and Sivadasan (2008) added one more species, D. veldkampii Kiran Raj \& Sivad. to this section. From D. woodrowii, it was differentiated based on characters such as, peduncles straight at maturity, rachis loosely rolled to form ringlet, racemes not articulated with peduncle,

Received: 15.10.2019; Revised \& Accepted: 20.12.2019

Published Online: 31.12.2019 callus densely hairy and c. $0.3 \mathrm{~mm}$ long, glumes wingless or minutely winged at apex, awn with well differentiated basal column (Kiran Raj \& Sivadasan, 2008). So far, this D. veldkampii is known from only two localities (Kiran Raj \& Sivadasan, 2008; Dileep \& Nair, 2015).

As a part of taxonomic and distributional study of the endemic herbaceous plants on lateritic plateaus of northern Western Ghats and Konkan, different populations of D. woodrowii have been studied to understand its range of morphological variations, microhabitat preferences, phenology and ecological adaptations. Study has shown that D. woodrowii shows wide range of morphological variations in forming circinate coiling, bending at first node, level of enclosing racemes in spathe-like sheath at maturity, hairiness, wing on upper glumes and awn length. Studies based on different populations revealed, D. veldkampii Kiran Raj \& Sivad. as conspecific with D. woodrowii. Details of range of morphological variations of $D$. woodrowii and comparison of D. veldkampii with D. woodrowii based on protologues are given in Table 1. It shows that distinguishing characters of $D$. veldkampii are within the variations of $D$. woodrowii.

Dimeria woodrowii Stapf, Hooker's Icon. Pl. 24: t. 2312. 1894; Hook.f., Fl. Brit. India 7: 104. 1896; Blatt. \& McCann, Bombay Grass. 8. 1935; T.Cooke, Fl. Bombay 3: 462.1958 (Repr. ed.): Bor, Grasses Burma, Ceylon, India \& Pakistan 144. 1960; B.G.Kulk., Fl. Sindhudurg 513. 1988; S.M.Almeida, Fl. Sawantwadi 2: 125. 1990; Laxmin. in Sharma et al., Fl. Maharashtra, Monocot. 470. 1996; S.Moulik, 
Table 1. Range of morphological variations in D. woodrowii and its comparison with D. veldkampii

\begin{tabular}{|c|c|c|c|}
\hline Character & $\begin{array}{l}\text { D. veldkampii } \\
\text { (From protologue) }\end{array}$ & $\begin{array}{l}\text { D. woodrowii } \\
\text { (From protologue) }\end{array}$ & $\begin{array}{l}\text { Field/morphological observations in } \\
\text { different populations of } D \text {. woodrowii }\end{array}$ \\
\hline Peduncles & Straight & Bends at maturity & $\begin{array}{l}\text { Bending of peduncles is a highly variable } \\
\text { character. On single individual, bent and } \\
\text { straight peduncles were observed }\end{array}$ \\
\hline Racemes & $\begin{array}{l}\text { Single or double } \\
\text { ringlets, loosely } \\
\text { rolled racemes }\end{array}$ & $\begin{array}{l}\text { Tightly rolled, form } \\
\text { raceme globule }\end{array}$ & $\begin{array}{l}\text { Varies from single to repeatedly roll and } \\
\text { loosely to tightly rolled racemes. Observed } \\
\text { from moist to dry climatic condition and } \\
\text { young to old raceme (Fig. } 1 \mathrm{~d}-\mathrm{j} \text { ) }\end{array}$ \\
\hline Raceme groups & $\begin{array}{l}\text { Fully emerge out } \\
\text { from spathe-like } \\
\text { sheath }\end{array}$ & $\begin{array}{l}\text { Enclosed in } \\
\text { spathe-like sheath } \\
\text { at maturity }\end{array}$ & $\begin{array}{l}\text { Enclosed to fully emerge from spathe-like } \\
\text { sheath at maturity (Fig. 1d-j) }\end{array}$ \\
\hline Callus & $\begin{array}{l}\text { c. } 0.3 \mathrm{~mm} \text {, densely } \\
\text { bearded }\end{array}$ & c. $0.1 \mathrm{~mm}$, hairy & $\begin{array}{l}\text { Within a single raceme, callus showed } \\
\text { variation in size }(0.1-0.3 \mathrm{~mm}) \text { and hairiness } \\
\text { pattern (Fig. } 1 \mathrm{k}, \mathrm{l})\end{array}$ \\
\hline Spikelets & $\begin{array}{l}\text { Coriaceous, } \\
\text { acuminate to aristate } \\
\text { at apex, yellowish }\end{array}$ & Coriaceous & $\begin{array}{l}\text { Coriaceous, acute at apex.Turn reddish in less } \\
\text { water exposed areas and early blooming } \\
\text { plants, while yellow in moist area and late } \\
\text { blooming plants. In some individuals, } \\
\text { on same plant one raceme can be seen with } \\
\text { reddish brown and other with yellowish } \\
\text { brown colour (Fig. 1d) }\end{array}$ \\
\hline Glumes & $\begin{array}{l}\text { Dorsally keeled } \\
\text { throughout, hairy } \\
\text { toward keeled apex; } \\
\text { upper glume with or } \\
\text { without minute } \\
\text { wing on back }\end{array}$ & $\begin{array}{l}\text { Dorsally rounded } \\
\text { at base, keeled at apex, } \\
\text { hairy along sides } \\
\text { below; upper glume } \\
\text { with a broad wing } \\
\text { at apex }\end{array}$ & $\begin{array}{l}\text { Range in variation of keel, wing and hairs } \\
\text { within single raceme (Fig. 2i). On single } \\
\text { raceme, glumes with or without wing as well } \\
\text { as glabrous to hairy on back. Generally } \\
\text { glumes of the upper spikelets of the raceme } \\
\text { are without keel or wing }\end{array}$ \\
\hline Awns & $\begin{array}{l}0.8-1.2 \mathrm{~cm} \text { long awn } \\
\text { with a well } \\
\text { differentiated basal } \\
\text { column }\end{array}$ & $\begin{array}{l}\text { Not } \\
\text { mentioned }\end{array}$ & $\begin{array}{l}0.2-1.4 \mathrm{~cm} \text { long awn. Upper spikelet of the } \\
\text { raceme with long awn and distinct column } \\
\text { while basal spikelet with reduced awn } \\
\text { without column (Fig. } 1 \mathrm{k} \text { ) }\end{array}$ \\
\hline $\begin{array}{l}\text { Disarticulation } \\
\text { of spikelets }\end{array}$ & $\begin{array}{l}\text { Early disarticulation } \\
\text { of the spikelets, i.e. } \\
\text { tachychorous }\end{array}$ & Not mentioned & $\begin{array}{l}\text { Single to double coiled racemes show } \\
\text { bradychorous to tachychorous dispersal } \\
\text { depending on varying degrees of moist } \\
\text { or dry climate condition (Fig. 1d-j) }\end{array}$ \\
\hline
\end{tabular}

Grasses \& Bamboos India 1: 285. 1997; Potdar et al., Grasses Maharashtra 127. 2012. Type: INDIA, Rutnagherry district, South of Bombay, s.d., Woodrow s.n. (holo K000245772 digital image!)

Dimeria veldkampii Kiran Raj \& Sivad., Novon 18: 18(2). 2008; Dileep \& Nair, Int. J. Advanced Res. 3: 658. 2015 syn. nov. Type: INDIA, Goa, North Goa district, Taleigao, c. 50 m, 27.10.2003, M.S. Kiran Raj 81073 (holo CALI digital image!; iso $\mathrm{MH}, \mathrm{MO})$.

Annuals. Culms c. $15 \mathrm{~cm}$ tall, erect, slender, nodes bearded; upper nodes geniculate or straight, internodes glabrous. Leaf sheath 2-6 $\mathrm{mm}$ long, sub-terete, glabrous; ligules c. $1 \mathrm{~mm}$ long, membranous; leaf blades linear, acuminate, $2-5 \times$ $0.1-0.4 \mathrm{~cm}$, bulbous based hairs on both surfaces. Peduncles 2.5-5 cm long, glabrous, straight to bend at maturity; racemes usually 2-digitate to subdigitate; $2-6 \mathrm{~cm}$ long, enclosed to fully emerge out from spathe-like sheath, singly to repeatedly rolled, loosely to tightly coiled to form hoop rachis smooth and glabrous, trigonous. Spikelets $3-4 \times$ 1.3-1.5 mm, obovate to oblong, pedicelled, awned; pedicels $0.5-1 \mathrm{~mm}$ long; callus $0.1-0.3 \mathrm{~mm}$ long, sparsely to densely hairy; lower glume 2.5-3 


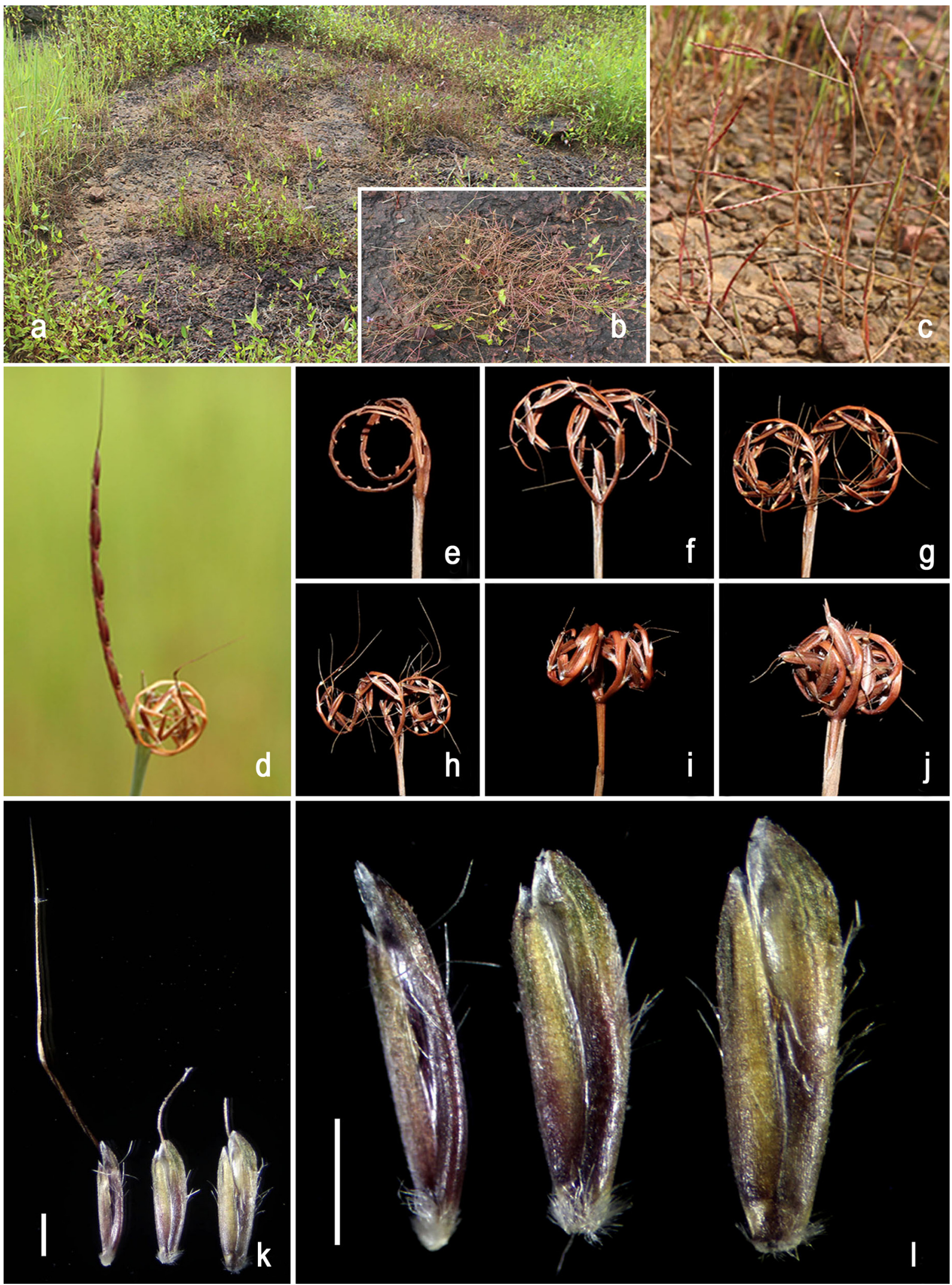

Fig. 1. Microhabitat, habit and diversity of circinate hoops in D. woodrowii Stapf: a. A view of microhabitat of $D$. woodrowii; $\mathbf{b}$. MicrohabitaiClose up view; c. Habit of $D$. woodrowii in its microhabitat (bends at first node); $\mathbf{d}-\mathbf{j}$. Spikelets on a single raceme forming hoops; $\mathbf{k}$. Spikelets with awn Upper, Middle, Lower (From left to right); I. Close up view of spikelets Upper, Middle, Lower (From left to right). Scale $1 \mathrm{~mm}$ 
$\times$ 0.3-0.5 mm long, oblong to lanceolate, coriaceous, compressed, rounded on keel, glabrous to sparsely hairy, apex acute to acuminate; upper glume 3-4 × 0.5-1 mm, oblong to lanceolate, coriaceous, glabrous to hairy, compressed, with or without wing at upper half, apex acute to acuminate, glabrous to hairy on back; lower lemma $2-2.5 \times 0.4-0.5 \mathrm{~mm}$, narrowly obovate, membranous, hyaline, 1-nerved, apex two toothed; palea absent; upper lemma 2.2-2.7 × 0.3-0.5 mm, oblanceolate, hyaline, cleft at apex, strong midrib produced into $0.2-1.4 \mathrm{~cm}$ long awn; awn reduced in lower spikelets while with distinct column in upper spikelet in a raceme or all the spikelets with long distinct column; palea absent. Lodicules 2. Stamens 2; anthers 0.7-1.5 mm long. Pistil c. 2 $\mathrm{mm}$ long. Caryopsis 2-2.3 $\times 0.4-0.5 \mathrm{~mm}$, laterally compressed, narrowly ovate.

Flowering \& fruiting: September-November.

Habitat: It grows usually on low elevation lateritic plateaus at Konkan (rarely at high elevations in northern Western Ghats) on exposed rocky surfaces.

Distribution: Goa, Maharashtra, Karnataka (Endemic to Western Ghats and Konkan).

Specimens examined: INDIA, Goa, North Goa, Bicholim, 27.10.2017, Rutuja R. Kolte RRK1266; Goa University Campus, 26.09.2017, Rutuja R. Kolte RRK1103; Taleigao, 23.10.1997, V.C. Joshi \& S. Rajkumar 357; South Goa, Loliem, 10.09.1997, V.C. Joshi \& S. Rajkumar 944; Ibid., 01.10.2018, Rutuja R. Kolte RRK1770; Vasco De Gama, 09.1909, R.K. Bhide s.n. (BLAT). Maharashtra, Ratnagiri, Champak Garden, 20.10.2017, Rutuja R. Kolte RRK1223; Ratnagiri, Phansop, 20.10.2017, Rutuja R. Kolte RRK1232 (Goa University Herbarium); Sindhudurg, Achirne, 18.09.2017, Rutuja R. Kolte RRK1102; Ibid., 20.11.2017, Rutuja R. Kolte RRK1307; Aronda, 28.09.1978, s.coll. (BLAT 109494); Kokare, 07.10.2017, Rutuja R. Kolte RRK1198; Padel Canteen titha, 17.09.2017, Rutuja R. Kolte RRK1041, RRK1051; Patgao, 17.09.2017, Rutuja R. Kolte RRK1055, RRK1065 (Goa University Herbarium).
Notes: On the sheet in Kew, two gatherings are available, viz. (i) Rutnagherry district, S. of Bombay, Coll. Woodrow and (ii) Division Goa, Marmagoa, Oct. 20, 1891, Coll. W.A. Talbot. No. 2557, Recd Sept. 1893. The first sheet was communicated to Kew by Lisboa in 1893 (vide sheet and protologue). However, the second gathering, in spite of collector's name and locality did not find place in protologue. In protologue, Stapf (1894) has mentioned, "HAB. India: Rutnagherry District, South of Bombay, Woodrow; near Goa”. Then Ratnagiri district was bordering Goa in South and hence the word near Goa, whereas Talbot's collection is from Marmagoa which is in South Goa district of Goa. Hence, it is clear that Stapf (1894) has referred only to Woodrow's collection prior to the publication. According to Bor (1952), a note by Woodrow on a sheet in DD, the specimen was collected by Bhiva Babajee from Karanjee, Ratnagiri District. Oct. 1892 (Dr. Prashant Pusalkar, pers. Comm.). However, there is no evidence to show that collection at $\mathrm{K}$ by Woodrow and DD from Bhiva Babajee are from same gathering.

Dimeria woodrowii grows in a range of microhabitats. Usually it grows on exposed rock surfaces, on very thin layer of soil or Cryptogamic mat (Fig. 1 a \& b). Availability of water varies among these microhabitats during intermittent dry spells during monsoon. Because of this, colour, hairiness, bending at first node and forming hoop of racemes vary. Flowering starts from month of September and after this period monsoon decreases gradually in post-monsoon period, plants face longer period of drought conditions. Thus depending upon local environmental conditions in microhabitat, plants show range in morphological variations.

\section{Acknowledgements}

Authors are thankful to Dr. Prashant Pusalkar, BSI; Dr. K.M. Manudev, Assistant Professor, Department of Botany, St. Joseph's College (Autonomous), Devagiri, Kerala for providing literature and 
specimen images and to Dr. Sharad Kambale, Assistant Professor, Department of Botany, MVP's ACS College, Tryambakeshwar, Nashik, Maharashtra for suggestions in the manuscript. KRR is grateful to Rufford foundation for financial support.

\section{Literature Cited}

BOR N.L. 1952. Notes on Asiatic Grasses: XI. The Genus Dimeria R.Br. in India and Burma. Kew Bulletin 7(4): 553-592.

CLAYTON W.D., HARMAN K.T. \& H. WILLIAMSON 2006. Grass Base: the online world grass flora. Available from: http://www.kew.org/data/ grasses-db.html. (Accessed on 15.01.2019).

DILEEP P. \& G.G. NAIR 2015. Dimeria veldkampii - A new record for South India. International Journal of Advanced Research 3(11): 657-662.

GOSAVI K.V.C., KAMBLE M.Y., CHANDORE A.N. \& S.R.YADAV 2016. A new species of Dimeria (Poaceae) from Andaman and Nicobar Islands, India. Phytotaxa 270(4): 295-300.
KIRAN RAJ M.S. 2008. Taxonomic revision of the subtribe Dimeriinae Hack. of Andropogoneae (Poaceae - Panicoideae) in Peninsular India. Submitted to University of Calicut (Unpublished).

KIRAN RAJ M.S. \& M. SIVADASAN 2008. A new species of Dimeria (Poaceae, Panicoideae, Andropogoneae) from Goa, India. Novon 18(2): 183-186.

MABBERLEY D.J. 2017. Mabberley's Plant-Book: A portable dictionary of plants, their classification and uses. Fourth Edition. Cambridge University Press, Cambridge.

NAYAR T.S., A.R. BEEGAM \& SIBI, M. 2014. Flowering Plants of the Western Ghats, India Volume 2. Jawaharlal Nehru Tropical Botanical Garden and Research Institute, Thiruvananthapuram. p.1150.

RAVI N., MOHANAN N. \& M.S. KIRAN RAJ 2001. Three new species of Poaceae from South India. Rheedea 11: 87-96.

SINGHP., KARTHIGEYAN K., LAKSHMINARASIMHAN P. \& S.S. DASH 2015. Endemic vascular plants of India. Botanical Survey of India, Kolkata. p.300.

STAPF O. 1894. Hooker's Icones Plantarum: Or figures, with brief descriptive characters and remarks, of new or rare plants, selected from the author's herbarium. Dulau \& Co., London. Volume 24. 